\title{
Modern aspects of the development of security in air transport under the conditions of air terrorism
}

\author{
Daniel Michalski ${ }^{1 *}$, Adam Radomyski ${ }^{1}$ \\ ${ }^{1}$ National Security and Logistics Faculty, Polish Air Force University
}

\begin{abstract}
OBJECTIVES: The authors determined the following aim of this article: identifying threats generated by air terrorism as well as characterizing the forms, methods, and manners.

METHODS: Authors used theoretical methods of research. The article presents research findings with regard to the organization and operation of security systems in civil air transport. At the article, the authors focused on air terrorism and security system in the airport.

RESULTS: The presented results of the study are not limited only to the theoretical aspects of terrorism. Authors also characterize organizational and technical undertakings that have already been implemented into security systems in aviation by national and intergovernmental institutions, responsible for its protection.

CONCLUSIONS: Regardless of the form of air terrorism and applied means, an important issue is a fact that every attempt to intercept an aerial asset is attractive for terrorists, due to the fact that each time it causes not only damage or destruction of the machine itself and the death of passengers, but it is also a real threat to airport infrastructure, installations and urban residents. In addition, the events are accompanied by high-profile media coverage.
\end{abstract}

Keywords: terrorism, security system, airport, hijack, checking passengers

* Corresponding author: d.michalski@law.mil.pl

OPEN ACcess (C) (i) () 2019 D. Michalski, A. Radomyski, published by War Studies University, Poland. This work is licensed under the Creative Commons Attribution-NonCommercial-NoDerivatives 4.0 License. 


\section{Introduction}

Air transport, in economic terms, is the activity of providing payable services, which result in carrying passengers and goods by air, as well as the implementation of auxiliary services (supporting) flight operations. A very important determinant of its development is the safety and security of air operations, including passengers on board aircraft and at airports. Due to their nature, air services have been linked to the risk of accidents since their beginnings. However, over one hundred years of the development of aviation, this risk has been so significantly minimised that today the plane is considered to be one of the safest means of transport. This state of affairs was possible to achieve, first and foremost, as a result of technical and organisational changes which have occurred in aviation. In this respect, it is necessary to emphasise the role and importance of safety management in aviation, which allows it to be maintained on an acceptable level of air mishaps, in particular air crashes.

Moreover, in order to properly respond to security threats, the entities organising transport processes need a well-planned and integrated concept of a security system that includes risk management, adapted to the local determinants, and diagnosed threats. A key issue is the development and efficient implementation of security programmes, which should be effective, consistent and comprehensive. This can also be referred to airport infrastructure, since both the national and international regulations, including the recommendations made by the International Civil Aviation Organisation (ICAO), impose a number of security requirements to be met by aviation entities.

The practice of the functioning of air transport proves that there is no middle way which could provide security for passengers. To the contrary, there are a number of issues that might reduce the risk of accidents and limit their negative consequences. In this case, however, one needs to be made aware that every undertaken action should be proportionate to the type and scale of the diagnosed threat. In addition, security should be seen as a set of integrated actions which include human, technical and organisational factors. This is a vital issue in the creation of effective security systems, because terrorist attacks against civilian air transport constitute a serious challenge for any airport, regardless of its size and location.

At this point, one can quote the words of Brian M. Jenkins who stated that terrorism is theatre and its audience is public opinion (Jenkins 1975, p. 64). The objects of terrorist 
attacks can be both parts of airport infrastructure, aircraft at airports and a flight itself. Terrorists may also attempt to hijack a passenger aircraft in order to use it as a weapon to attack a selected object (such as a critical government building, critical infrastructure installations/facilities). One should not exclude hijacking of a civil aircraft in order to use it later in a suicide attack, or in an attack on another aircraft at an airport, or in an attack on selected installations of airport infrastructure. Another type of terrorist threat may be an attack launched at air traffic control and airport management systems.

Bearing in mind the outlined problem situation, the authors determined the following aim for this article: identifying threats generated by air terrorism as well as highlighting the types, methods and manner.

Thus, the major objective of the study has been formulated in the form of the following question: What are the hazards generated by air terrorism and what can be done to increase the efficiency of civil aviation security?

When looking for a solution to the main problem, the authors primarily used scientific theoretical methods, in particular analysis, synthesis, comparison, analogy, generalisation, and deduction.

\section{Defining air terrorism}

The word terror derives from Latin, meaning the use of violence, rape, or cruelty in order to intimidate someone. In light of the New Universal Encyclopedia PWN, terrorism denotes differently ideologically motivated, planned and organised actions of individuals or groups, resulting in the violation of the existing legal order so as to compel certain behaviour and benefits, often affecting the good of the general public, on the part of authorities and society. The essence of the phenomenon of terrorism is defined as follows: "the essence of terrorism consists in ostentatious and maximalist, purposeful attack against the innocent general public (civil persons) and public goods for indirect impact upon a real political or ideological opponent." (Koziej 2006, p. 31). Against this background, it is possible to define one of its forms - air terrorism. By adopting some generalisation, it can be assumed that air terrorism denotes "all criminal acts threatening the safety of international air navigation" (Jałoszyński 2002, p. 16). The Polish equivalent, frequently used to describe this form of terrorism, is air piracy, which 
is defined as: "a robbery, an act of violence, a holdup, an act of plundering made against an aircraft in air space, (...); it is a terrorist hijacking of an aircraft under the threat of using a gun and explosives in relation to the crew or passengers"(Kopaliński 2000, p. 195). The category of air piracy is very often associated with the concept of unlawful seizure or unlawful interference. In this respect, it should be noted that in accordance with international regulations, unlawful interference usually refers to:

1. the use of violence against a person on board an aircraft during a flight, provided this act endangers the safety of the aircraft;

2. the destruction of an aircraft or causing damage which prevents the continuation of a flight or which could jeopardise the safety of the aircraft during a flight;

3. planting or causing to plant (in whatever manner) on board an aircraft, a device or a substance that can damage the aircraft or lead to such damage that may prevent its flight or jeopardise its safety during a flight;

4. the provision of information, being aware that it is false, thus threatening the safety of the aircraft during a flight;

5. unlawful and intentional use of any devices, substances or weapons when committing an act of violence against a person at the airport supporting international civil aviation, which will or may cause a serious injury or death;

6. destruction or serious damage to airport equipment for international civil aviation, to a civil aircraft present at the airport, or disruption of airport services, if any of these attacks threatens or may threaten the security of the airport (Manual of Civil Aviation Against Unlawful Interference 1996, pp. 2-3).

In an attempt to more specifically define the concept of aerial terrorism, the authors treat it as an act of unlawful interference in the affairs of international civil aviation and its facilities, including the unlawful capture of an aircraft, sabotage or an armed attack directed against an aircraft operating in international air carriage or against ground installations exploited by such carriage (Barcik 2004, p. 28). It is also possible to encounter a different definition of this phenomenon, where it is treated as a criminal act targeted against aviation resources (Marcinko 2008).

Another interesting definition of terrorism has been formulated by an Israeli scholar, Hillel Avihai. For the sake of his academic studies, he created a definition of this phenomenon in which he assumed that: "aviation terrorism refers to intentional, sometimes indiscriminate acts of violence targeted against civilian/commercial aircraft and/or against passengers and/or crew on board, committed by individuals, secret agents 
or subnational groups in order to promote political objectives, which are unrelated to achieving personal gains" (Avihai 2009, pp. 35-36). However, in light of the applicable legal acts (ICAO 2017), this definition is incomplete because it does not include acts of violence targeted at elements of airport infrastructure, ground navigation systems, computer systems which assist air traffic management, or other activities threatening the safety and security of air navigation.

In conclusion, regardless of the manner of defining the phenomenon of aerial terrorism (wider or narrower), it seems obvious that it is one of the forms of violence, which is reflected in the media, which is psychological and propagandistic in its nature, since its purpose is to intimidate people and disrupt the most vital foundations that affect the stability of international air navigation.

\section{Diagnosis of a terrorist threat in relation to civil air transport}

In practice, ensuring full safety and security for air transport proves difficult and complex. Its complexity derives from the fact that the security and safety of civil aviation has several aspects. The first aspect of safety and security is directly associated with a terrorist threat to airport infrastructure against terrorist attacks (Glen 2013, pp. 18-20), as for example in the case of European airports, which became the target of terrorist attacks several times in the 1990s. A couple of examples are listed below:

1. 30 June 2007 at the airport located in the Scottish County of Renfrewshire, near Glasgow, a car containing a bomb rammed the glass doors of the main airport terminal, stopping at the protection gates;

2. January 24, 2011 in Russia in Domodedovo, home to an international airport, in the vicinity of Moscow, there was an attack in which 37 people were killed and at least 180 were injured. The force of the explosion was comparable with the force of an explosion of $5 \mathrm{~kg}$ of TNT The explosive was filled with metal elements to increase its power of destruction;

3. 18 July 2012, on the bus at Burgas airport, a bomb went off. As a result of the explosion caused by a suicide bomber, seven people were killed and 25 others were injured;

4. March 22, 2016, terrorist attacks occurred in Belgium: two explosions at the airport in Brussels, and successive explosives in an underground station. Two suicide bombers 


\section{Security and Defence Quarterly}

ISSN 2300-8741 eISSN 2544-994X

2019 September Volume 26 Number 4

https://doi.org/10.35467/sdq/110553

detonated explosive materials at the entrance to the international airport in Brussels; another suicide terrorist detonated an explosive device in an underground station located in the vicinity of the European Parliament;

5. June 28, 2016 at Ataturk International Airport in Istanbul, Turkey, three terrorists opened fire at the departure terminal, and then detonated vests filled with explosives (the so-called suicide vest), killing more than forty people and injuring 150 others.

Another aspect of air transport security refers to the protection of aircraft and passengers on board. This pertains, among others, to the control of passengers and their baggage by specialist services. At this stage, it should be pointed out that not only the passengers and their cabin baggage undergo a safety check. The inspection also covers registered baggage before it is loaded on board the aircraft (Compa 2013). These types of attacks are particularly dangerous and tragic in their consequences. In the majority of cases, the events involve the death of a great number of people, as proved by the example of October 31, 2015 year when a Russian airlines A321, flying from the Sinai Peninsula to St. Petersburg, was blown apart by a bomb, which was planted under one of the seats. The explosion on board the A321 was equal to one kilogram of explosive material (TNT). The Islamic State, whose members managed to bypass the security system at the international airport in Sharm el-Sheikh on the Sinai Peninsula, claimed responsibility for this terrorist attack. As a result of the blast, 224 people on board the aircraft were killed.

Despite the occurrence of such events in civil aviation, due to excellent organization of the security system, numerous attacks were successfully prevented, as proved by the following examples:

1. in 2006, the plan to detonate explosives aboard several aircraft operating transatlantic flights was successfully halted. The perpetrators planned to use explosive devices hidden in beverage bottles;

2. another bombing attempt occurred in 2009 , when a terrorist hid an explosive device in a suitcase containing underwear;

3. 2009, Al-Qaeda in the Arabian Peninsula attempted to attack a US aircraft flying from the Netherlands to the United States, using a sophisticated explosive device consisting of powder and liquid;

4. in October 2010, two packages containing explosives were detected in two planes flying from Yemen to the United States. The first explosive device was detected during a stopover in Dubai, and the other during a stopover in the UK. The investigation revealed that a powerful explosive pentrite (PET) was hidden inside printer cartridges. 
The analysis of cases of air terrorism indicates that terrorist groups launch attacks on aircraft mainly during take-off or landing. For this purpose, they reach for special military resources such as Man Portable Air Defence Systems - MANPADS or less sophisticated means of destruction, such as small arms or RPGs. The threat of MANPADS increased even further after the outbreak of civil war in Libya at the beginning of 2011 and in Syria. This is confirmed by subsequent intelligence reports which stress that MANPADS are already in the hands of Al-Qaeda terrorists in Islamic Maghreb. Some reports confirm that MANPADS stolen from Libyan arsenals reached Niger, the Gaza Strip and the Sinai Peninsula. Other reports also indicate that the Taliban received some MANPADS from Iran. One cannot exclude the possibility of using systems based on the latest technology in the near future, including modules that interfere or disrupt the work of electronic onboard instruments installed in aircraft.

Aircraft themselves have become an excellent tool for terrorist attacks (Compa and Załęski 2012, p. 85). A tangible example might be the terrorist attacks of 11 September 2001 , when the terrorists managed to spread unrest among the international community on an unprecedented scale. The 2001 attacks also caused a shift in the military field, in which a new concept of an aircraft type Renegade appeared. This concept began to be used in relation to identifying and distinguishing civil aircraft that are a potential target of a hijack and capture by terrorists. An aircraft classified as the Renegade is regarded as a potential means of carrying out a terrorist attack from the air. There are three degrees in the system of classification of these aircraft: suspect, probable and confirmed. The aircraft classified as the Renegade complies with the prevention provisions, based on national regulations, laid down by competent public authorities (defined generally for all NATO countries).

An extremely important issue which should be taken into account in evaluating a terrorist threat is the large diversity in the use of multiple kinds and types of aircraft, such as passenger aircraft, transport aircraft, helicopters, light aircraft, ultra-light aircraft, aircraft models controlled by radio etc. An equally important issue is also the ability to use various loads such as aviation fuel, explosives, and toxic materials in such aircraft. In this regard, in developed scenarios, experts predict e.g. hazards of hijacking a passenger plane or another aircraft loaded with fuel or explosives in order to destroy a particular object or cause massive losses among the civilian population (Radomyski 2017, pp. 107-108). Experts on terrorism also assume that one of the types of attack on a mass population could involve use of an aerial platform (manned or unmanned) as a means 
of transport to discharge (spray) toxic chemical, biological or radioactive substances (Compa 2012).

On the whole, it can be said that regardless of the form of aerial terrorism and the means used, an important issue is that every attempt to intercept an air transport asset, from the viewpoint of terrorists, is attractive due to the fact that each time it not only causes damage or destruction to the machine itself and the death of passengers, but is also a real threat to airport infrastructure, installations and residents of urban conurbations. In addition, the events are usually accompanied by extensive media coverage (Kulczyński 2008, pp. 12-14). By analysing the spectrum of terrorist threats, it is possible to indicate several kinds of attacks which can be executed at an airport. They are as follows:

- attempts to assassinate a particular person;

- bomb attacks;

- hijacking a wheeled vehicle or an aircraft;

- taking hostages.

There is also a group of measures that can be used at an airport. These may entail (Glen 2014, pp. 13-14)

- the use of explosives;

- the use of portable missile systems to attack aircraft while taking off or landing;

- the use of RPGs and small arms;

- the use of hijacked aircraft to attack certain installations;

- the use of anti-aircraft mines;

- acts of cyber-terrorism.

\section{Contemporary determinants for shaping security in civil air transport}

At first glance, it is possible to observe that a huge impact on the level of safety and security in civil air transport is exerted by a properly organised and implemented process of security control as part of the passenger check-in procedure at airports. The implementation of a number of novel technologies and even more restrictive measures to support security systems can, in extreme cases, cause social resistance regarding the legitimacy of such actions, respecting privacy or civil rights. 
Based on the examples of acts of terror directed against civil air transport, one may reach a conclusion that despite various efforts made by the governments of various countries, whose objective was to improve aviation safety and security, there are still critical areas. One of them is the area of passengers, which has further expanded with new services and facilities (Zielinski 2010, p. 60). It results from the fact that on the premises of the terminal there are not only duty-free shops and restaurants, but also specialist services, such as boutiques, shopping malls, banks, cinemas and other entertainment and culture facilities for VIP passengers, chapels, business centres, beauty salons and sports centres, among others. In the case of large airports, new places such as beauty salons and children's play areas are still emerging. Despite the development of new facilities, the primary functions associated both with aircraft maintenance (fuel depots, service) and industrial functions connected with logistics, distribution and processing of perishable goods, aviation industry, or special economic zones still remain. A large terminal aside from the vast concourse and facilities for properly extended piers usually has a multistore superstructure e.g. housing two levels for the departing passengers. The sensitivity of the terminal is mainly due to the presence of bystanders and passengers who did not undergo any inspections.

Naturally, the availability of a terminal is somehow limited due to the enclosure of restricted areas, for instance for persons eligible for a flight or holders of a Schengen visa (mandatory for holders of a transit visa and for other passengers after crossing this zone). From the standpoint of airport security, a key factor is the huge control area, where the potential effects of its intrusion can threaten sensitive structures of the airport. In this respect, it should be emphasised that as part of the airport infrastructure, international regulations (recommendations made by the International Civil Aviation Organisation (ICAO Annex 14 and 17) impose a number of requirements to be met by the investor. Designers have to balance the architectural concepts with security requirements (e.g. suitable location of restricted areas, inspection areas, and access zones). When building aprons for aircraft, it is also necessary to take into account the place where a plane that is the object of unlawful interference will be moved (the so-called Vera procedure). These places should be the most favourable from the viewpoint of forceful actions, isolated from outside access and the media; they must also not endanger other objects. They should also allow immediate access for security and rescue services as well as "a secure approach" for special units. Every structure mounted inside the airport protection zone, even outside the fence, must be designed and constructed in such a manner that in confrontation with a plane, it collapses in the first place (Szucki et al. 2001). 
Based on the findings of proper research, it should be stressed that passenger terminals are the most commonly attacked objects of airport infrastructure. The passenger terminal is listed in first place as part of the infrastructure subjected to special protection (Liedel 2003 , p. 14). The open parts of terminals which are particularly exposed to terrorist attacks are vulnerable to terrorist attacks, since staying in these sections does not even require possession of a travel document. The people who stay there are not controlled by security services. It is much more difficult to launch an attack in the airside area, where accessibility for the general public is limited. These places can be merely accessed by passengers who have been security checked and by airport staff with a valid pass, entitling them to stay in a given zone, having also passed through a security check. On the grounds of an airport, there is a likelihood of other attacks such as planting, or the threat of planting explosive devices at airport facilities and installations; attacking people staying on the premises of the airport or taking hostages in the airport area. These are special cases requiring the cooperation of all services in order to ensure the safety of the entire airport. Terrorism at airports also includes attacks on the aircraft on the tarmac or bringing devices and explosives or other items prohibited for air carriage on board.

One of the tendencies of recent terrorist attacks is to use the personnel employed at the airport to facilitate an attack or to become directly involved in an attack. This is the aftermath of recruitment conducted by terrorist organisations among airport employees. The recruitment usually takes place through social networking sites, in particular Facebook, which can provide an almost unlimited number of potential volunteers. It should be noted that recruitment can also be conducted in a traditional manner in other circles, for example among mosque worshippers, family members or friends. In the course of the study conducted by the International Institute of Countering Terrorism in 2015, Facebook profiles which belonged to airport workers all over Europe were detected. The key issue was the fact that these people had access to the airside area (zones) at airports. Despite the policy of increased security at airports, the number of cases in which shortcomings in the employment process are found tends to be growing; for example, Egyptian security forces carried out a thorough examination of workers at the airport of Sharm El-Sheikh after the crash of a Russian plane over the Sinai Peninsula in October 2015. Their objective was to assess the possibility of smuggling a bomb aboard a plane by an airport worker (Hoffman 2006). At the end of January 2016, it appeared that a mechanic, a worker responsible for loading baggage and two policemen from Sharm El-Sheikh airport were arrested on charges of involvement in the attack. 


\section{Diagnosis of ways, methods and measures used to counter air terrorism in civil air transport}

The quoted examples of ways, methods and tools used by terrorists not only indicate high determination on the part of terrorists, but also the capability of terrorist organisations to launch attacks against international air transport in different parts of the world. Apparently, civil aircraft and airport infrastructure are very attractive targets for terrorists.

Based on the results of relevant research in the field of risk assessment of individual objects constituting the infrastructure of airports, it can be stated that the objects which are particularly vulnerable to terrorist attacks are terminals, as due to their function, construction and the difficulty of monitoring all the people in the terminal, especially in the landside area, they remain particularly special. In this respect, a very important measure is a well-organised terminal monitoring system able to identify all the suspiciously or strangely behaving individuals. From the perspective of the first contact with a passenger arriving at the airport, a surprisingly big, though often underestimated, role is played by a handling agent. According to the authors, such personnel, following proper training, may play a very important role in airport security. In the first place, this concerns the staff employed at the check-in desk. These persons can be the first to identify risk through observation of a checked-in passenger whose behaviour may significantly differ from the commonly accepted norm (Bednarczyk 2016). Attention should also be paid to those accompanying the passengers. Passenger service personnel are a kind of a border zone, separating the landside area from the airside one. The observations regarding those checked-in should be immediately passed to airport service workers, who can carry out a detailed examination of the suspect passenger, thwarting their criminal intentions. On the basis of the conducted studies, it is possible to adopt a thesis that the level of airport security is affected by numerous factors and people who, through their work in such an area, are integral elements responsible for maintaining security at an acceptable level. This is due to the fact that every passenger, before boarding a plane, must go through check-in and security checks, during which he should be monitored. Despite the difficulties for passengers, it is their safety which remains of primary importance; therefore, state-of-the-art technologies are exploited for its enhancement. 
Escalating terrorist activity was also the main condition for the development of new legal and organisational objectives aimed at increasing the effectiveness of countering air terrorism. They have been included in the basic national documents of particular states, members of NATO and the EU. They also include issues for countering terrorism by improving the safety systems of critical infrastructure and the civilian population, especially in large urban conurbations. Great emphasis has been put on this in the United States, where new assumptions enabling development of more effective forms of counterterrorism have been introduced. One of the key doctrinal assumptions in this regard was to eliminate such threats by the use of modern and technological security measures, including the implementation of individual civil aircraft protection systems and improvement of the protection of airports on an increasingly wider scale.

By making a detailed analysis of a number of government measures adopted in the United States, it can be assumed that the issue of countering terrorism in the 21st century will constitute a permanent element of an international policy to improve the safety and security of civil aviation worldwide. An example of involvement in the solution to this problem is also an action undertaken by the United Nations, whose General Assembly adopted resolutions nos. 59/90 in December 2004 "Prevention of the illicit transfer and unauthorised access to and use of man-portable air defence systems". They were proclaimed by states that showed willingness to take up the obligation and make an effort to counter and prevent illicit trafficking of MANPADS on the national, regional and international arena. In addition, the United Nations plans and programmes restricting actions regarding illicit trade in small arms.

A wide range of activities targeting air terrorism was also developed by NATO. They fit well into the context of operations other than war (Military Operations Other Than War - MOOTW). They are characterised by The doctrine of Stability Operations and Support Operations FM 3-07. In this document, one of the tasks of the armed forces within the framework of stability operations is combating terrorism (CBT). It may assume a defensive form (AT-antiterrorism) aimed at preventing acts of terror or an offensive form (CT- Counterterrorism). A key role in countering air terrorism is played by operations with the use of special forces detached from the armed forces of particular countries. Other important documents that define the rules of using military force in combating acts of terror are as follows: the concept of operational reinforcement of the NATO air-defence system against a possible terrorist attack, using civil aircraft (MCM-062-2) and the revised NATO Directive on the functioning of an integrated force OP NATO- 
MC54/1- II amendment. One of the standard measures for the protection of objects at risk of a terrorist attack from the air are temporary or permanent No-Fly Zones (NFZ) or Flight Restricted Zones (FRZ). No-Fly Zone or Flight Restricted Zone is an airspace of defined dimensions over land, internal waters and territorial waters, in which flights are prohibited (Radomyski 2018). No-fly zones or flight restricted zones are preceded by identification zones, in which a final verification of an aircraft as confirmed target or accidental intruders is provided. Assigning air space is agreed upon at any one time with civil air traffic supervisory authorities, which are responsible for the further distribution of information about establishing prohibited zones to all users (Radomyski 2018, pp. 73-74). In order to ensure additional safety in no-fly zones, alarm systems are to be mounted additionally, e.g. lanterns with modulated laser light which inform pilots they are approaching a no-fly zone, using pre-arranged signals (also in daytime). Such a permanent zone for banning flights was introduced over Washington after September 11, 2001. In accordance with the decision of the Federal Aviation Administration, there is a ban on flights within a radius of approximately $22 \mathrm{~km}$ over Washington. It does not apply to commercial passenger airlines.

The introduction of the above-mentioned undertakings which strengthen the security of airspace has also become a standard during the organisation of other major events such as: the economic summit of G-8, G-20, the World Economic Forum in Davos, and NATO summits. It is also extremely important to ensure safety during sporting events on an international scale (e.g. the Olympic Games, world and European football championships).

Practice shows that a very important factor determining the effective countering of air terrorism is to combine all the elements that build the system of state security into one coherent whole. Apparently, it seems relatively simple to achieve, although in practice it proves to be much more difficult. This results from the complex structure of the security system. The difficulties in the organisation of an effective system for countering air terrorism also has a technical, organisational and legal background. 


\section{Conclusions}

Summing up the previous considerations, it is possible to risk the statement that air terrorism is a major threat to national security in the 21st century. At present, it is difficult to predict a new form of terrorist attack by means of an aircraft. Nevertheless, the analysis of previous attacks suggests that every attempt of that kind might entail great destruction and human loss (both on the aircraft and on the ground) as well as considerable public outcry. In this respect, by making an analysis of hazards generated in air space, one may risk the statement that air terrorism may become one of the most dangerous sources of destabilisation of air security in the near future, both in a regional (state) and international dimension. Among other things, this results from the fact that aviation today is not only the fastest, but a more and more common and accessible means of transport. This attracts terrorists, who consider the aircraft an excellent tool for achieving their goals (Karpowicz and Klich 2004, p. 7).

In conclusion, it can be said that regardless of the form of air terrorism and means applied, an important issue is the fact that every attempt to intercept an aerial asset is attractive for terrorists, due to the fact that each time it causes not only damage, or destruction of the machine itself and the death of passengers, but is also a real threat to airport infrastructure, installations and urban residents. In addition, the events are accompanied by high-profile media coverage.

Based on the obtained study findings, it can be stated that in the near future, the development of the organisation of the state's security system, including the objects of air infrastructure for the needs of increasing the effectiveness of countering air terrorism, will require changes in the methods and manner of using the forces and resources, modification of operating procedures and changes in legislation. The above statement suggests that the contents presented in this article do not constitute a full and comprehensive solution to the problem of effective countering of air terrorism; therefore, these issues require further scientific research. Despite its incompleteness, the results collected during the existing studies relating to the organisation of safety and security systems in the protection of the most important properties of critical state infrastructure, large and spectacular international sporting events and economic and political summits indicate that their planning should take into account the use of specialised military forces including aviation and ground-based air defence means. 
On the basis of an analysis of hazards generated by air terrorism, it is possible to predict that in the future, one may expect an intensification of these types of actions not only conducted using hijacked passenger planes, which can be increasingly difficult to execute, but above all other flying vehicles (manned and unmanned), which can be used to drop an explosive (e.g. a dirty bomb), spray chemicals or biological agents (Karkowiak 2018, pp. 31-36).

Acknowledgements: Scientific work was carried out in the framework of the project "Automation of information and decision-making processes in air defence under the conditions of modelled air threat of troops and critical infrastructure facilities" no. GB/5/2018/209/2018/DA F

\section{References}

Avihai, H., 2009. Aviation Terrorism. Evolution, Motivation and Escalations. Saarbrücken: VDM Verlag.

Barcik, J., 2004. Akt terrorystyczny i jego sprawca w świetle prawa międzynarodowego i wewnętrznego. Warszawa.

Bednarczyk, A., 2016. Odprawa biletowo-bagażowa i kontrola bezpieczeństwa w porcie lotniczym. Studenckie Zeszyty Naukowe, Bezpieczeństwo powietrzne państwa. Innowacyjność, nauka, technika, 1.

Cieślak, G., 2010 Infrastruktura krytyczna lotnisk - kuracja ze skutkami ubocznymi, Terroryzm, 1. Compa, T., 2013. Bezpieczeństwo operacji w portach lotniczych. Obstuga handlingowa. Dęblin: WSOSP.

Compa, T., 2012. Ochrona lotnictwa przed aktami bezprawnej ingerencji. Dęblin: WSOSP.

Compa, T., Załęski, K., 2012. Terroryzm w lotnictwie. Dęblin: WSOSP.

Glen, A., 2014. Terroryzm lotniczy. AON, Warszawa.

Jałoszyński, K., 2002. Współczesne zagrożenie terroryzmem powietrznym, kierunki przedsięwzięć w zakresie przeciwdziałania mu oraz walki z tym zjawiskiem In: J. Gotowała (ed.), materiaty z konferencji naukowej entitled „Bezpieczne Niebo” 2002, Warszawa: AON.

Jenkins, B.M., 1975. International Terrorism: A New mode of Conflict, In: Carlton, D., Shaerf C. ed, International Terrorism and World Security, London: Crom Helm.

Karpowicz, J., Klich, E., 2004. Bezpieczeństwo lotów i ochrona lotnictwa przed atakami bezprawnej ingerencji, Warszawa: AON.

Karkowiak, E., 2018. Unmanned Aerial Vehicles in the Security Service and as a New Tool in the Hands of Criminals, Safety and Defense, 4 (1).

Kopaliński W., 2000. Stownik wyrazów obcych, Warszawa.

Koziej, S., 2006. Między piektem a rajem: szare bezpieczeństwo na progu XXI. Toruń: Adam Marszałek. 
Liedel, K., ed., 2003. Zwalczanie terroryzmu lotniczego, Warszawa: Jurysta.

Marcinko, M., 2008. Wybrane aspekty walki z terroryzmem w prawie międzynarodowym, Dęblin: WSOSP.

ICAO. 2017. Annex 17 to the Convention on International Civil Aviation: Security - Safeguarding International Civil Aviation Against Acts of Unlawful Interference, 10th ed., 2017

Międzynarodowa Organizacja Lotnictwa Cywilnego, ed., 1996. Podręcznik ochrony lotnictwa cywilnego przed atakami bezprawnej ingerencji. Warszawa: V.

Radomyski, A., 2018. Współczesne aspekty przeciwdziałania terroryzmowi lotniczemu In: Bezpieczeństwo Polski w drugiej dekadzie XXI wieku. Szanse wyzwania ryzyko i zagrożenia, ed. P. Polsko, K. Załęski, M. Bracio, Dąbrowa Górnicza: Akademia WSB.

Radomyski, A., 2017. Kształtowanie bezpieczeństwa powietrznego jako integralnego elementu obronności państwa, Przegląd Naukowy o Obronności, 3.

Radomyski, A., 2018. Współczesne determinanty bezpieczeństwa powietrznego państwa, Historia i Polityka, 25 (32).

Szucki, J., Gąsiorowski, M., Zając, G. Szczelina, M., 2011. Zarządzanie bezpieczeństwem lotnictwa cywilnego, Wrocław: Dolnośląska Szkoła Wyższa.

Zieliński, M., 2010. Bezpieczeństwo w porcie lotniczym, Zeszyty Naukowe Akademii Marynarki Wojennej, 4.

\section{Autors:}

\section{Daniel Michalski, PhD, Cpt.}

D https://orcid.org/0000-0001-8202-6738

\section{Adam Radomyski, DSc. PhD, Col (ret.)}

Dean of the Faculty of National Security and Logistics, Polish Air Force University, Dęblin (iD) https://orcid.org/0000-0001-7522-308X 